\title{
Moving towards sustainable development goals: initiatives of Bangladeshi youth organizations during corona outbreak
}

\author{
Sayed Md. Kamruzzaman \\ Peoples' Friendship University of Russia (RUDN University), \\ 6 Miklukho-Maklaya St, Moscow, 117198, Russian Federation \\ sayedkamruzzaman51@gmail.com
}

\begin{abstract}
The purposes of this paper are to measure youth organizations' contribution during corona crisis that has impact on SDGs, to know the activities that have done for the society to identify which activity have impact on which SDGs, thus, it can be measured the sustainability of the organization itself. Bangladesh marching towards sustainable development goals undoubtedly will reach its apex by 2030; Bangladeshi youth are dedicating themselves broader during this pandemic. Youth organizations are straight away there for nations by providing relief, creating awareness in the society, health assistance such that providing PPE stocks (masks, hand sanitizers and PPE suits) and through lump sum donations. The statistical analysis has been done in SPSS and the respondents are from Bangladesh covering eight districts. Youth organizations from Dhaka and Chittagong are the top tier actors; the main goal of this study is to measure the Bangladeshi youth-led organizations' contribution during corona crisis and to know the challenges they faced while working on field, and besides, how the funds they have raised to implement their goals. This paper defines the brief visualization of the parameters (location of youth organizations in Bangladesh, amount of funds, approaches of raising funds, reviews of government and member supports, reviews about the health consciousness against corona virus among Bangladeshis, brief discussion on youth organizations' expectations to combat those challenges they faced during societal contribution in Bangladesh) to extract their contribution's impact over Bangladeshi community during corona crisis. Youth organizations rated member support, government support. Their initiatives have impact on goals 1 , $2,8,10,11$. These youth led organizations have great impact on social change, culture and beliefs thus contributing to SDG 11 (cities and communities); the findings will act as their means of advocacy by notifying stakeholders and will motive youth leaders.
\end{abstract}

Keywords: Bangladesh, youth, youth-led organizations, COVID-19, corona crisis, sustainable development goals

Acknowledgements and Funding. Inspiration and motivation always works behind any types of venture. Above all, I thank Almighty who have nourished us with plenty of resources in this world that paves the way to develop ourselves. In performing this article on "Moving towards Sustainable Development Goals: Initiatives of Bangladeshi Youth Organi- 
zations during Corona Outbreak", I needed to survey Bangladeshi youth organizations who supported me a lot by answering my required questions within the given period. I would like to show my profound gratitude to Ms. Margarita Redina, Editor-in-Chief of the RUDN Journal of Ecology and Life Safety, who coordinates such an esteemed journal for the RUDN students and so on. My greatest thanks pass to the editorial board who paves the way to publish journal in a systematic way. Finally, I will dedicate this article to those who are Frontline Fighters who saved life and served in the society during COVID-19. Without their support, the world communities would die and the world become an empty vessels; perhaps, world would remain with no human footprint or healthy and sustainable remarks in the world. My profound respect goes to those communities who fought against COVID-19.

Article history: received 23.11.2020; revised 01.12.2020.

For citation: Kamruzzaman SMd. Moving towards sustainable development goals: initiatives of Bangladeshi youth organizations during corona outbreak. RUDN Journal of Ecology and Life Safety. 2020;28(4):417-427. http://dx.doi.org/10.22363/2313-2310-202028-4-417-427

\title{
Движение к целям устойчивого развития: инициативы бангладешских молодежных организаций во время вспышки коронавируса
}

\author{
С.Мд. Камруззаман \\ Российский университет дружбы народов, \\ Российская Федерачия, 117198, Москва, ул. Миклухо-Маклая, д. 6 \\ sayedkamruzzaman51@gmail.com
}

\begin{abstract}
Аннотация. Цели исследования - измерить вклад молодежных организаций во время коронакризиса в развитие целей устойчивого развития (ЦУР) и определить влияние на различные ЦУР деятельности, проделанной обществом. В работе над целями устойчивого развития Бангладеш достигнет пика к 2030 году. Во время пандемии коронавируса бангладешская молодежь проявляет большую самоотдачу. Молодежные организации оказывают помощь путем повышения осведомленности в обществе, оказания медицинской помощи, предоставления запасных частей СИЗ (масок, дезинфицирующих средств для рук и костюмов СИЗ), а также посредством единовременных пожертвований. В исследовании участвовали респонденты из восьми районов Бангладеш, статистический анализ проведен в SPSS. Изучены проблемы, с которыми столкнулись молодежные организации при работе на местах, определено количество собранных ими для реализации своих целей средств. Выявлено, что молодежные организации из Дакки и Читтагонга являются ведущими. Дан краткий обзор параметров (местонахождение молодежных организаций, объем средств и подходы к их сбору, поддержка со стороны правительства, сознательность в отношении к собственному здоровью населения Бангладеш в условиях коронавируса, ожидания от борьбы с возникшими во время общественной деятельности проблемами) с целью продемонстрировать влияние этой деятельности на бангладешское сообщество во время коронакризиса. Установлено, что инициативы молодежных организаций, поддерживаемые государством, влияют на цели 1, 2, 8, 10, 11. Они оказывают сильное воздействие на социальные изменения, культуру и убеждения, тем самым способствуя достижению ЦУР 11 (города и сообщества). Полученные результаты привлекают к их деятельности заинтересованные стороны и мотивируют молодежь.
\end{abstract}

Ключевые слова: Бангладеш, молодежь, молодежные организации, COVID-19, коронакризис, цели устойчивого развития 
Благодарности и финансирование. Вдохновение и мотивация всегда подкрепляют любые начинания. Прежде всего, я благодарю Всевышнего, который дал нам множество ресурсов в этом мире на пути нашего развития. При написании данной статьи требовалось опросить молодежные организации Бангладеш, которые оказали мне большую поддержку, отвечая на необходимые вопросы в течение определенного периода. Выражаю огромную благодарность М.М. Рединой, главному редактору журнала «Вестник Российского университета дружбы народов. Серия: Экология и безопасность жизнедеятельности», координирующей столь уважаемый и важный для студентов РУДН журнал, а также редколлегии, обеспечивающей его систематическую публикацию. Наконец, я посвящаю эту статью бойцам передовой, спасающим жизни и служащим обществу во время COVID-19. Без их поддержки мировые сообщества умрут и мир станет пустым сосудом (возможно, останется без человеческого влияния или здоровых и устойчивых стремлений). Я глубоко уважаю сообщества, борющиеся с COVID-19.

История статьи: поступила в редакцию 23.11.2020; принята к публикации 01.12.2020.

Для цитирования: Kamruzzaman S.Md. Moving towards sustainable development goals: initiatives of Bangladeshi youth organizations during corona outbreak // Вестник Российского университета дружбы народов. Серия: Экология и безопасность жизнедеятельности. 2020. Т. 28. № 4. С. 417-427. http://dx.doi.org/10.22363/2313-2310-2020-28-4-417-427

\section{Introduction: Bangladeshi youth and current corona situation}

Bangladesh is going through an era when number of youth is increasing and now it is 47.6 million people aged 10-24 years, or $20 \%$ of the population, out of total 158.5 million (UNFPA); that is a sign when country significantly develops herself in technology and socio-economic sectors.

National Federation for Youth Organizations (NFYO) is the planning chamber of youth organizations in the nation which incorporates 480 member organizations and around 4,000 youth organizations as its primary members [1].

Young people working for society have been awarded in different platforms to work for the society, for their social movement and proactive engagement in humanitarian activities; such as US based non for profit organization "Asia Society”, Forbes, US Department of States, 2016 Queen's Young Leaders, etc. Young leaders are representing Bangladesh from multi-cultural organizations like Facebook, WHO, UNESCO, NASAA and so on. Over the world, Bangladeshi youth has already drawn a footprint of leadership excellence in both international and national platforms through their charismatic qualities and cultural diversification. It has to be discussed in this paper the initiatives taken by youth organizations in Bangladeshi community that have remarkable impact on sustainable development goals of a country.

$32,484,997$ corona virus cases found last updated on $25^{\text {th }}$ September, 2020 according to Worldometers. According to the data of $27^{\text {th }}$ July, 2020 published by World Health Organization, 226,225 have been confirmed as corona positive; $1,24,417$ have undergone for corona test whereas over 125,683 have already recovered [2]. Bangladesh is the $15^{\text {th }}$ ranked country according to Worldometers; 356,767 total cases in Bangladesh and total recovered 267,024 [3].

Due to pandemic situation, many countries are in recession right now. Unlike other countries, this pandemic has given uncertainty to business, organizations and 
daily activities. But Bangladesh GDP has not dropped down due to corona outbreak. This development rate is likewise much over the financial development prediction given to Bangladesh by the World Bank (WB) at 1.6\%, International Monetary Fund (IMF) at 3.8\% and Asian Development Bank (ADB) at 4.5\% for 2020. While these speculation predictions are for the schedule year 2020, however the BBS development prediction is for the 2019-2020 money related year. Indeed, the Bangladesh government accepts that the economy is on target to accomplish 8.2\% development rate in 2020-2021 and furthermore anticipates that the economy should bounce back at a higher movement than before after the pandemic is finished (The Financial Express, August, 28). There is an understood message that the economy isn't just journeying back to pre-pandemic levels yet in addition will outperform that [4].

\section{Materials and methods}

Since youth are engaging themselves in many social activities, it has been surveyed the youth organizations to get insights about what they have done and how they have done and how the things happened during COVID-19. The objective to study their initiatives during this pandemic in Bangladesh:

- to know the activities that have done for the society to identify which activity have impact on which SDGs;

- to know how they collected funds and what are the shortcoming of collecting funds since positive money flow ensures the life of an organizations; thus, it can be measured the sustainability of the organization itself;

- to get insights about their views and expectations on Bangladesh government since government has arranged many programs for them and allocated budget from the development for the youth organizations of Bangladesh;

- to get a summary of how much precautions are followed by Bangladeshis during COVID-19 that are noticed while working at the field; since a healthconscious and aware society reflect a country as "Protective Country" that bring progress in both socio-economically and culturally;

- to get informed about the recommendations and share in this paper so that the concern authority come forward to support youth organizations so that the country SDGs are properly fulfilled and satisfy the needful as per the requirements. Such that, funding support, advocacy and other supporting arrangements can be done by government and other concerns by getting a glance of this paper.

\section{Government promoting youth organizations}

Youth organizations are working relentlessly to contribute to the society attain the SDGs through Vision 2021, Vision 2041 and the UN Sustainable Development Goals (2016-2030); hence, they are doing social works and government is also promoting the youth engagement in many sectors in Bangladesh. National Youth Policy 2017, National Skill Development Policy 2011, Sheikh Hasina National Youth Development Institute Act, 2017 have been initiated by the Bangladesh government to empower youth of Bangladesh that contributes to the sustainable development. Priority areas of government for youth development are empowerment (education, training, employment and entrepreneurship, development 
of information technologies), health care and recreation, good governance (civic participation, social participation and social safety), sustainable development goals (sustainable development goals, education in and awareness of the environment, environment-friendly agriculture and industrialization, safe food and commodity marketing), equitable development, building healthy society, globalization and survey and research [5]. Government has accommodated many programs to build youth engagement in attaining SDGs. Thus, youth empowerment has been increased in Bangladesh in last decades; they have now multiple sectors and opportunities to work for the betterment of the society as well as for the motherland. Access to Information (a2i) in Bangladesh has come out with "Innovation Lab" which is entailed with innovation fund, youth innovation programs motivating youth of Bangladesh.

\section{Bangladeshi youth organizations working against corona crisis}

34 organizations have been surveyed located in Bangladesh and among them 24 youth organizations are from Dhaka (the capital of Bangladesh) and 9 organizations are from Chittagong (one of the most industrialized districts of Bangladesh) and the other one is from Khulna. Their core working areas are ICT, social welfare, education, skill development, international affair development, legal aid, food distribution, humanitarian aid and social awareness and youth advocacy (Table 1).

Location

\begin{tabular}{ccccc}
\hline & & Frequency & Percent & Valid percent \\
\hline \multirow{4}{*}{ Valid } & Dhaka & 24 & 70.6 & 70.6 \\
& Chittagong & 9 & 26.5 & 26.5 \\
& Khulna & 1 & 2.9 & 2.9 \\
& Total & 34 & 100.0 & 100.0 \\
\hline
\end{tabular}

The core activities the surveyed youth organizations of Bangladesh are doing to contribute to the SDGs are:

- advocacy \& youth empowering initiatives;

- health, education, human rights, climate change and disaster management;

- work for underprivileged children;

- youth skills development training;

- help hunger peoples around the world;

- eradication of poverty;

- help people of the country;

- assurance of fundamental right of poor people;

- promotion of social entrepreneurship and foster youth skill development programs in order to bring out positive social change;

- social welfare which includes charitable giving and also creating social awareness from different aspects according to the need of the society;

- building innovation culture around the Bangladesh;

- supplying the voice of young generation regarding current global issues;

- minimization of unemployment rate by managing works for youth;

- education, youth development, blood donation, waste management, women empowerment. 


\section{The youth organizations activities to combat corona crisis}

During this pandemic, youth organizations have moved forward to stand beside needy people and they are building awareness since the breakout of this pandemic. Study shows that they are distributing relief, providing emergency ambulance support, distributing health facilities to the refugees, food distribution, cash support, awareness campaign, hygiene materials distribution, community radio programme, IEC materials distribution, online schooling to students, awareness campaign, aid for old homes, camping to create corona awareness, helping transgender community by the help of collaboration. Details about the activities along with the names of organizations have been mentioned below.

Relief distribution. Dhrubotara Youth Development Foundation, Green HR Professionals Bangladesh, Food for the Hungry, Somikoron Academic Centre, Badhon Ramganj Foundation, Youth for Better Future Society, Youth School for Social Entrepreneurs (YSSE), Pashe Achi Initiative, Positive Youth Development Society of Bangladesh, Jadumoni Foundation, Bangladesh Innovation Forum, Youth for Bangladesh, Mainia Youth Forum, Lighter Youth Foundation, ProjectDebi, Bidyanondo Foundation distributed relief to needy people. This initiative impacts on SDG 1 - No Poverty and SDG 2 - Zero Hunger.

Food distribution. YPSA (Young Power in Social Action), Bidyanondo Foundation, Youth Nexus, Genesis Foundation, Badhon Ramganj Foundation, Pashe Achi Initiative, Nobarun Youth Charity Foundation, Impact Bangladesh, Lighter Youth Foundation, Ignite Youth Foundation, Youth for Social Aid (YFSA), Zone for Humanity, Youth for Bangladesh, Gontobbo Youth Foundation, Bidyanondo Foundation also distributed food for the poor. They provided food for Iftar to the poor at the month of Ramadan 2020.

Fund donation to poor. Green HR Professionals Bangladesh, Somikoron Academic Centre, National Youth Foundation Bangladesh, HYLO (Humanitarian \& Youth Leading Organization), Jadumoni Foundation, Chittagong Young Star Society, Bidyanondo Foundation supported poor by handing over cash.

Corona hygiene item distribution. Dhrubotara Youth Development Foundation, YPSA (Young Power in Social Action), Food for the Hungry, Genesis Foundation, Badhon Ramganj Foundation, Youth for Better Future Society, Youth Nexus, Chittagong Young Star Society, Human Shadow, Mainia Youth Forum, Youth Environmental Opportunities (YEO), Ignite Youth Foundation, Youth for Social Aid (YFSA), Bidyanondo Foundation distributed corona protective items like PPE, masks, gloves, sanitizer and so on. This has impact on SDG 3 - Good Health and Well-Being.

COVID-19 awareness. Dhrubotara Youth Development Foundation, YPSA (Young Power in Social Action), Young Elite Community Club, Youth for Better Future Society, National Youth Foundation Bangladesh, Bangladesh Youth Empowerment Society, Futontoh Kishor Songo, Youth School for Social Entrepreneurs, Positive Youth Development Society of Bangladesh, Bangladesh Innovation Forum, Youth Nexus, Gontobbo Youth Foundation, Mainia Youth Forum. Youth School for Social Entrepreneurs organized 9 corona awareness programs to raise awareness among mass people. 
Activities that have impacted in SDG goals

\begin{tabular}{ll}
\hline \multicolumn{1}{c}{ SDGs } & \multicolumn{1}{c}{ Activities during COVID-19 } \\
\hline Goal 1. No poverty & Helping poor and underprivileged with providing cash support \\
\hline Goal 2. Zero hunger & Distributing cooked foods, food groceries to the poor and underprivileged \\
\hline $\begin{array}{l}\text { Goal 3. Good health } \\
\text { and well-being }\end{array}$ & $\begin{array}{l}\text { Distributing corona protective items like PPE, mask, sanitizers and hand } \\
\text { gloves, etc. }\end{array}$ \\
\hline $\begin{array}{l}\text { Goal 8. Decent work } \\
\text { and economic growth }\end{array}$ & Corona initiatives and financing small businesses to sustain in the market \\
\hline Goal 10. Reduced inequality & Supporting transgender \\
\hline $\begin{array}{l}\text { Goal 11. Sustainable cities } \\
\text { and communities }\end{array}$ & $\begin{array}{l}\text { Youth organizations initiatives to community engagement and work } \\
\text { for the wellness of human-being can provide a sustainable city }\end{array}$ \\
\hline
\end{tabular}

Out of box activities done by youth organizations:

- online schooling by Young Elite Community Club;

- emergency ambulance support;

- awareness program by UK doctor organized by Bangladesh Youth Empowerment Society;

- supporting small ventures by Pashe Achi Initiative;

- policy advocacy by Dhrubotara Youth Development Foundation;

- call support to a2i by Youth Nexus;

- support to transgender community by ProjectDebi;

$-500+$ online medical support by Ignite Youth Foundation.

These activities have greater impact on SDGs such that youth organizations' steps to fight for the pandemic reflect goal 3 - Good Health and Well-Being. Nonetheless, this table indicates how and which SDGs are affected by which activities done by Youth Organizations of Bangladesh (Table 2).

\section{Sources of funds, its sufficiency and total expenditure for COVID-19}

According to the study, 23 organizations out 34 raised funds from their member's donation; however, other sources of government fund, international organizational fund, individual fund and crowd funding.

$67.6 \%$ the youth organizations expressed that they got the satisfactory member support for the corona combating initiatives during this hard time. 1 organization mentioned that they got international fund and other 10 organizations said that they collected their funds from individual donors, private organizations and crowd-funding and social media promotions to get funds to support the initiatives to fight against the pandemic (Table 3).

Table 3

Sources of fund

\begin{tabular}{cccccc}
\hline & & Frequency & Percent & Valid percent & Cumulative percent \\
\hline \multirow{4}{*}{ Valid } & International fund & 1 & 2.9 & 2.9 & 2.9 \\
& Members' donation & 23 & 67.6 & 67.6 & 70.6 \\
& Others & 10 & 29.4 & 29.4 & 100.0 \\
& Total & 34 & 100.0 & 100.0 & \\
\hline
\end{tabular}


Number of members

\begin{tabular}{cccccc}
\hline & & Frequency & Percent & Valid percent & Cumulative percent \\
\hline \multirow{4}{*}{ Valid } & Below 100 & 14 & 41.2 & 41.2 & 41.2 \\
& $101-200$ & 2 & 5.9 & 5.9 & 47.1 \\
& $201-300$ & 4 & 11.8 & 11.8 & 58.8 \\
& $301-400$ & 2 & 5.9 & 5.9 & 64.7 \\
& 401 and above & 12 & 35.3 & 35.3 & 100.0 \\
& Total & 34 & 100.0 & 100.0 & \\
\hline
\end{tabular}

Table 5

Statistics

\begin{tabular}{cccccc}
\hline & & $\begin{array}{c}\text { Sources } \\
\text { of fund }\end{array}$ & $\begin{array}{c}\text { Rating to Governmental } \\
\text { support towards Youth ORGs }\end{array}$ & $\begin{array}{c}\text { Sufficiency } \\
\text { of funds }\end{array}$ & $\begin{array}{c}\text { Rating to member support } \\
\text { during corona crisis }\end{array}$ \\
\hline \multirow{2}{*}{$\mathbf{N}$} & $\begin{array}{c}\text { Valid } \\
\text { Missing }\end{array}$ & 34 & 34 & 34 & 34 \\
& 0 & 0 & 0 & 0 \\
\hline Mean & 3.29412 & 3.00000 & 3.29412 & 4.61765 \\
\hline Median & 3.00000 & 3.00000 & 3.00000 & 5.00000 \\
\hline Mode & 3.000 & 3.000 & 3.000 & 5.000 \\
\hline Standard deviation & .578892 & 1.180652 & 1.087934 & .551291 \\
\hline Variance & .335 & 1.394 & 1.184 & .304 \\
\hline Range & 3.000 & 4.000 & 4.000 & 2.000 \\
\hline
\end{tabular}

Additionally, $35.3 \%$ of youth organizations have 401 members and above, whilst $41.2 \%$ have below 100 members, still they are getting enough support from their members to work during corona crisis in Bangladesh (Table 4).

Statistics shows that out of 34 youth organizations, 23 youth organizations collected funds from member support was good (very good - 5; good - 4; 3 - moderate; 2 - poor; 1 - very poor) and members donated for their organizational purpose like distribution, relief purpose and for other support (Table 5).

Table 6

Rating to governmental support towards youth ORGs

\begin{tabular}{cccccc}
\hline & & Frequency & Percent & Valid percent & Cumulative percent \\
\hline \multirow{4}{*}{ Valid } & Very bad & 4 & 11.8 & 11.8 & 11.8 \\
& Bad & 7 & 20.6 & 20.6 & 32.4 \\
& Moderate & 12 & 35.3 & 35.3 & 67.6 \\
& Good & 7 & 20.6 & 20.6 & 88.2 \\
& Very good & 4 & 11.8 & 11.8 & 100.0 \\
& Total & 34 & 100.0 & 100.0 & \\
\hline
\end{tabular}

However, it has been shown to the statistics that government was rated moderate as to refer the mean score of 3.29 which means it was not that much satisfactory since government arrange different plans for the development and maintenance for the youth organizations of Bangladesh (Table 6); they also provide policy advocacy to the youth organizations but unfortunately, according to the statistics, youth organizations did not get enough support from the Bangladeshi government during this pandemic (Table 6). Youth organizations mostly got support from their members in both field work level support and financial support since most of the surveyed youth organizations raised fund from their members' donations (Table 7). 
Rating to member support during corona crisis

\begin{tabular}{cccccc}
\hline & & Frequency & Percent & Valid percent & Cumulative percent \\
\hline \multirow{4}{*}{ Valid } & Moderate & 1 & 2.9 & 2.9 & 2.9 \\
& Satisfactory & 11 & 32.4 & 32.4 & 35.3 \\
& Very satisfactory & 22 & 64.7 & 64.7 & 100.0 \\
& Total & 34 & 100.0 & 100.0 & \\
\hline
\end{tabular}

Table 7 shows that 22 organizations rated member support as very satisfactory and 11 organizations rated member support as satisfactory. On the other hand, government support is not that satisfactory enough to work for the country to combat COVID-19.

\section{Fund sufficiency and approximate expenditure to combat COVID-19}

Though member support during corona crisis was satisfactory enough but fund to support community was not sufficient enough. They need more fund to do the needful and therefore, youth organizations are seeking government support to operate their humanitarian and social initiatives smoothly. Statistics shows that $47.1 \%$ of youth organizations or 16 youth organizations out of 34 mentioned that the fund allocated for the plan was not sufficient (Table 8).

Table 8

Sufficiency of funds

\begin{tabular}{cccccc}
\hline & & Frequency & Percent & Valid percent & Cumulative percent \\
\hline \multirow{4}{*}{ Valid } & Very insufficient & 2 & 5.9 & 5.9 & 5.9 \\
& Insufficient & 4 & 11.8 & 11.8 & 17.6 \\
& Moderate & 16 & 47.1 & 47.1 & 64.7 \\
& Sufficient & 6 & 17.6 & 17.6 & 82.4 \\
& Sufficient enough & 6 & 17.6 & 17.6 & 100.0 \\
& Total & 34 & 100.0 & 100.0 & \\
\hline
\end{tabular}

Expenditure for corona crisis

\begin{tabular}{cccccc}
\hline & & Frequency & Percent & Valid percent & Cumulativep \\
\hline \multirow{4}{*}{ Valid } & Below BDT. 10,000 & 5 & 14.7 & 14.7 & 14.7 \\
& BDT. 10,000-50,000 & 6 & 17.6 & 17.6 & 32.4 \\
& BDT. 51,000-1,00,000 & 5 & 14.7 & 14.7 & 47.1 \\
& Above 1,00,000 & 18 & 52.9 & 52.9 & 100.0 \\
& Total & 34 & 100.0 & 100.0 & \\
\hline
\end{tabular}

Survey conducted to 34 youth organizations and they shared that $52.9 \%$ of youth organizations or 18 youth organizations expressed that they had spent above BDT. 100,000 for the purpose of serving communities during corona crisis (Table 9).

\section{Health precautions noticed while working on field during COVID-19}

Government of People's Republic of Bangladesh has arranged many programs to raise awareness against COVID-19; thus, they do television live, radio programs and so on. Youth organizations noticed lack of health precautions among 
people of Bangladesh which is life-threatening. Statistics showed that only $11.8 \%$ of people who received their relief and for whom they worked for followed health precautions against corona virus and $41.2 \%$ of surveyed youth organizations followed health safety against COVID-19 (Table 10). Thenceforth, youth organizations relentlessly worked for communities to combat COVID-19 and make the city healthy and safe from corona virus. Youth organizations risk their life to work for the communities during corona crisis in Bangladesh that has remarkable impact on SDG mentioned above at Table 2.

Table 10

Rating on health consciousness noticed while working on corona crisis

\begin{tabular}{cccccc}
\hline & & Frequency & Percent & Valid percent & Cumulative percent \\
\hline \multirow{4}{*}{ Valid } & Very poor & 1 & 2.9 & 2.9 & 2.9 \\
& Poor & 7 & 20.6 & 20.6 & 23.5 \\
& Moderate & 14 & 41.2 & 41.2 & 64.7 \\
& Good & 8 & 23.5 & 23.5 & 88.2 \\
& Very good & 4 & 11.8 & 11.8 & 100.0 \\
& Total & 34 & 100.0 & 100.0 & \\
\hline
\end{tabular}

\section{Conclusion}

Bangladesh youth organization are serving their best to support communities and they arrange many plans to move forward. Youth organizations are putting their effort to SDG that bring prosperity of a country. Thenceforth, it has been asked youth organizations to recommend necessary measures to have the greater efficiency in operation. Such that: signing;

- engaging our community from the beginning of a project planning and de-

- assurance of transparency in financial transaction from the top level management;

- financial support from NGOs and local government that can bring youth organizations smooth money flow to run their operation effectively;

- providing more collaboration with government, NPOs \& NGOs to get funds and collaborative support can be exchanged among them;

- government funded training programs can be arranged so that young leaders can run their organizations with least mismanagement and efficiently with the highest level of coordination;

- specific policy should be taken to encourage corporate houses to donate for the youth organizations.

To sum up all the recommendations, it can be said that government should allocate funds for active youth organizations since youth are the powerhouse; and youth organizations are the practice field of those powerhouses. So, government should focus more on the facilities that can be provided to them; therefore, this initiatives will bring uplift of SDG of a country; so as Bangladesh. COVID-19 initiatives impacted on SDG but due to insufficient fund, they lag behind in regular operations. If government and giant actors of Bangladesh move forward to support youth organizations, they can move forward thousand times for the development of a country, for the betterment of communities that have also impact on sustainable development goals. 


\section{References}

[1] Bangladesh National Federation of Youth Organisations in Bangladesh (NFYOB). APYouthNet. 2020. Available from: http://apyouthnet.ilo.org/network/bangladesh-nationalfederation-of-youth-organisations-in-bangladesh-nfyob\#: :text=National $\% 20$ Federation $\%$ 20of $\% 20$ Youth $\% 20$ Organisations $\% 20$ in $\% 20$ Bangladesh $\% 20$ (NFYOB) $\% 20$ is $\% 20$ the, orga nizations\%20as\%20its\%20primary\%20member (accessed: 23.11.2020).

[2] WHO COVID-19 weekly update from 27 July, 2020. WHO. 2020. Available from: https://www.who.int/docs/default-source/searo/bangladesh/covid-19-who-bangladeshsituation-reports/who-covid-19-update-22-20200727.pdf?sfvrsn=d69469dc_2 (accessed 23.11.2020).

[3] Coronavirus update (live): 59,118,313 cases and 1,395,930 deaths from COVID-19 virus pandemic. Worldometers.info. 2020. Available from: https://www.worldometers.info/ coronavirus/\#countries (accessed: 25.09.2020).

[4] Mahmood M. On Bangladesh GDP in the time of coronavirus. The Financial Express. 5th September 2020. Available from: https://thefinancialexpress.com.bd/views/onbangladesh-gdp-in-the-time-of-coronavirus-1599314452 (accessed: 23.11.2020).

[5] National Youth Policy 2017. Available from: https://dyd.portal.gov.bd/sites/default/ files/files/dyd.portal.gov.bd/policies/21e565b2_252f_4f80_bfce_31a1cb33163d/Draft\% 20English\%20Version\%20of\%20National\%20Youth\%20Policy\%202017\%20(1).pdf (accessed: 23.11.2020).

\section{Сведения об авторе:}

Камруззаман Сайед Мд., магистр экономических наук, Российский университет дружбы народов. E-mail: sayedkamruzzaman51@gmail.com

\section{Bio note:}

Sayed Md. Kamruzzaman, Master of Sciences in Economics, Peoples' Friendship University of Russia (RUDN University).E-mail: sayedkamruzzaman51@gmail.com 